\title{
INTEGRATION OF SURFACE WATER PROTECTION INTO LAND MANAGEMENT IN UKRAINE: CASE STUDY OF THE SERET RIVER
}

\author{
Roman Kuryltsiv ${ }^{1 凶}$, Edward Sankowski², Nadiia Kryshenyk ${ }^{3}$, Agnieszka Rutkowska ${ }^{4}$, \\ Tomasz Noszczyk ${ }^{5}$, Józef Hernik ${ }^{6}$ \\ ${ }^{1}$ Department of Cadastre of Territory, Lviv Polytechnic National University, 12, Stepana Bandery str., 79013, Lviv \\ ${ }^{2}$ College of Arts and Sciences, University of Oklahoma, 455 W. Lindsey St., Room 625, Norman, OK 73019 USA \\ ${ }^{3}$ Project office, Lviv Polytechnic National University, 12, Stepana Bandery str., 79013, Lviv, Ukraine \\ ${ }^{4}$ Department of Applied Mathematics, University of Agriculture in Krakow, ul. Balicka 253 C, 30-149 Kraków \\ ${ }^{5}$ Department of Planning and Landscape Architecture, University of Agriculture in Krakow, ul. Balicka 253 C, 30-149 Kraków \\ ${ }^{6}$ Department of Land Management and Landscape Architecture, University of Agriculture in Krakow, ul. Balicka 253 C, 30-149 Kraków
}

\section{ABSTRACT}

\section{Aim of the study}

The aim of the article is to analyze current approaches and investigate some possible new approaches to planning and implementation of restrictions related to the protection of water and aimed at the regulation of land use.

\begin{abstract}
Material and methods
The proposed approach to surface water protection suggests imposing water protection restrictions of land use. This requires developing a land use management project. Designing water protection zones and nearshore protective belts is based on the consideration of options generated by geo-information modeling and use of remote sensing data. The operational options of ArcGIS 10.7 were used as basic software for the performance of the spatial analysis of data. The research territory for seeking confirmation of the proposed methods of projecting water protection zones and near-shore protective belts covered a part of the Seret river and its basin, located within the administrative borders of the Zalishchyky district of the Ternopil region.
\end{abstract}

\section{Results and conclusions}

The results of our research demonstrate that development of a land management project consisting in establishing water protection zones and near-shore protective belts with a specific regime of farming within relevant borders should become one of the most important mechanisms to prevent contamination, reduce flood risk, and improve sanitary-hygienic conditions of water-defined entities, processes, and activities. While developing the land management project, the authors performed calculation of the width of the water protection zone according to the principle of the reference value of an optimal width of the belt, which could catch the surface slope runoff.

Keywords: environment protection, land management, water protection zone, flood risk reduction, near-shore protective belt 


\section{INTRODUCTION}

Environmental protection and rational use of land resources are obligatory elements of the process of social development of Ukraine, because land resources create a foundation for people's livelihood, as well as those aspects of the economy for which the State is responsible. Furthermore, protection of land, reclamation and use of the land that does not exhaust its resources are among the preconditions of sustainable development of the country. "Sustainable development" is a concept with a complex history and current meaning, that is often mentioned in planning and implementing societal development (Sankowski et al., 2016).

All waters on the territory of Ukraine are part of the national wealth of the people of Ukraine, and are among the natural fundamentals of its economic development and social well-being. In the conditions of an increased anthropogenic burden on the environment, development of social production, and increased material needs, there is a necessity to develop and follow specific rules of water resources use, their rational utilization and environmental protection (Water Code of Ukraine, 1995).

Nowadays, the excessive pollution of water bodies with various harmful substances is the consequence of inefficient and sometimes even illegal use of water fund lands, agricultural lands, and plowing of slopes of the near-shore protective belts. In the 1990s, misuse resulted in building up of the banks of water passages and internal water bodies, as well as environmentally hazardous use of agricultural lands neighboring the water bodies. This has created preconditions for large-scale pollution of water bodies by pesticides and fertilizers, which are used for the needs of agricultural production (Holian et al., 2015).

The situation is also aggravated by the process of implementation of the European Directives, regulating the environmental block, particularly "On establishment of a framework for Community action in the field of water policy" (Directive 2000/60/EC... 2000), "On the assessment and management of flood risks" (Directive 2007/60/EC... 2007) "Concerning establishing a framework for Community action in the field of marine environmental policy" (Directive 2008/56/ EC... 2008), "On the quality of water intended for human consumption" (Council Directive 98/83/EC...
1998), "Concerning protection of waters against pollution caused by nitrates from agricultural sources" (Council Directive 91/676/EEC... 1991), "Concerning urban waste-water treatment" (Council Directive 91/271/EEC... 1991), which are defined as a primary element of the Association Agreement between the EU and Ukraine.

Thus, in current conditions, application of water protection restrictions of land use in water protection zones and near-shore protective belts is one of the most important challenges to save water resources. Those restrictions are intended to establish a regime of use of near-shore areas, preventing its pollution, exhaustion, destruction of near-water plants and animals, and reduction of flow fluctuation (Pokydko and Martyn, 2012). At present, there exist legal regulations in Ukraine concerning water protection zones to prevent water pollution and destruction of plants and animals, and to reduce flow fluctuations. Details of the regulations have been presented in the next sections of this paper.

Thus, an important task of land management is to argue for new approaches to shaping water protection restrictions of land utilization, which will contribute to a societal initiative to protect aspects of nature in near-shore territory along with minimal consumption of water resources. Such an argument builds on a data-driven and mathematically appropriate approach, which supports but is logically distinct from normative judgments about environmental protection and improvement. Making the argument requires scientific expertise, in conjunction with well-supported societally generated normative judgments expressing the values of Ukraine.

\section{MATERIAL AND METHODS}

The authors of the research studied the issue of establishing water protection zones and near-shore protective belts. The methodic approaches to projecting water protection zones are developed involving the options of geo-information modeling and using remote sensing data. Archival aerial photographs (2016) with high resolution $(1 \mathrm{~m})$ were used in the research process. Based on aerial photography, a topographic plan of the territory at a scale of 1: 5000 was created. The researchers used additional geo-spatial data, 
particularly a digital model of local topography, and mapping of soils of the studied territory. The vector and topographic maps were created based on aerial photography materials. The operational options of ArcGIS 10.7 served as basic software for completing the spatial analysis of data (particularly such options as vectorization, bufferization, and use of the tools of map algebra).

A part of the Seret river and its basin, which are located within the administrative borders of Zalishchyky district in the Ternopil region, were chosen as the testing territory for the proposed methodological instruments of designing water protection zones and near-shore protective belts.

Determining the borders of near-shore protective belts, in contrast to the borders of water protection zones, is done on the basis of a linear principle, automatically within the fixed limits, area of water bodies, and steepness of the neighboring slope. Conversely, designing water protection zones requires determination of their internal and external borders. An internal border of a water protection zone coincides with the long-term annual minimum water level. The external border normally refers to contours of agricultural lands, roads and forest belts, borders of flood plains, terraces above flood plains, edges of slopes, gills and ravines, and is determined by the line of 10-year flood records. Calculation of the width of a water protection zone $\left(W_{z}[\mathrm{~m}]\right)$ is performed in this paper by determining an optimal width of the belt, which can catch the surface slope runoff. The transition from the reference value to the actual one with consideration of other conditions of the slope is derived by introducing the appropriate coefficients according to the following formula (Land management. Land management projects... 2009):

$$
W_{z}=A_{1}+L_{p}
$$

particularly

$$
\mathrm{L}_{\mathrm{p}}=\mathrm{L}_{\mathrm{o}} \cdot \mathrm{K}_{1} \cdot \mathrm{K}_{2} \cdot \mathrm{K}_{3} \cdot \mathrm{K}_{4} \cdot \mathrm{K}_{5} \cdot \mathrm{K}_{6} \pm \mathrm{L}_{\mathrm{i}}
$$

where:

$A_{1}[m]$ - the distance from the riverbank at the longterm daily mean water level to the border of the 100 year floodplain. If the distance is less than $100 \mathrm{~m}$ then $\mathrm{A}_{1}=100 \mathrm{~m}$
$\mathrm{L}_{\mathrm{p}}[\mathrm{m}]$ - the distance from the border of the 100 year floodplain to the external border of the water protection zone;

$\mathrm{L}_{\mathrm{o}}[\mathrm{m}]$ - the width of the water protection zone in average conditions, according to Table 1. For example, it equals $700 \mathrm{~m}$ for deciduous forest on sandy loam soil with a slope of northern exposure and $2.5^{\circ}$ degrees.

$\mathrm{K}_{1}, \mathrm{~K}_{2}, \mathrm{~K}_{3}, \mathrm{~K}_{4}, \mathrm{~K}_{5}, \mathrm{~K}_{6}$ - the coefficients of transition, which are determined according to Table 2 for various types of land cover, soil textures, slope exposures, etc. It can be observed that the coefficients are 'corrections' to $\mathrm{L}_{\mathrm{o}}$ due to conditions that are different from 'average'.

The reason for the use of $\mathrm{K}_{1}-\mathrm{K}_{6}$ is that, for example, the forested land is a huge filter creating a barrier against erosion and noise. It accumulates moisture, dust, smoke, harmful gases, and cancer-inducing and radioactive substances. One hectare of a coniferous forest, for example, gathers from 30 to $70 \mathrm{t}$ of dust per year, purifies $18 \mathrm{mln} \mathrm{m}^{3}$ of air, absorbs $5 \mathrm{t}$ of carbon dioxide, disengages $4 \mathrm{t}$ of oxygen and up to $2 \mathrm{t}$ of phytoncides of ether oils, etc. That is why the $\mathrm{K}_{2}$ coefficient is less than 1 for forested areas.

$\mathrm{L}_{\mathrm{i}}[\mathrm{m}]$ - the correction of the $\mathrm{L}_{\mathrm{p}}$, which considers the change of the slope, namely:

$$
\mathrm{L}_{\mathrm{i}}=0.27 \cdot \mathrm{I} \cdot \mathrm{L}_{\mathrm{o}} \cdot \mathrm{K}_{1} \cdot \mathrm{K}_{2} \cdot \mathrm{K}_{3} \cdot \mathrm{K}_{4} \cdot \mathrm{K}_{5} \cdot \mathrm{K}_{6}
$$

where:

I [rad] is the difference between the actual slope and $2.5^{\circ}$; under the slope above $2.5^{\circ}$, it is positive and under the slope under $2.5^{\circ}$ it is negative.

Soil texture is conceived as shared contents of soil particles (aggregates) with different sizes and forms in it. Those particles are designated as mechanical elements of mineral, organic and organic-mineral origin.

Sand $(1-0.05 \mathrm{~mm})$ is characterized by high permeability, it does not expand, and it is inelastic. Sand has no structure, is non-viscous and dispersive when dry; consists of separate grains, sometimes with tiny particles. Sand clay is lightly plastic or non-plastic; the soil is easily ground when dry. In dry conditions, it is of sufficient viscosity, and produces little dust. It is 
Table 1. The width of water protection zones by reference to average conditions along large rivers

\begin{tabular}{|c|c|c|c|c|}
\hline \multirow{3}{*}{ Characteristics of the forest and land } & \multicolumn{3}{|c|}{ Width of the water protection zone $\left(L_{p}\right) \mathrm{m}$} & \multirow{3}{*}{$\begin{array}{l}\text { Width of the water } \\
\text { protection zone under } \\
\text { zero degree of slope, } \mathrm{m}\end{array}$} \\
\hline & \multicolumn{3}{|c|}{ Slope exposures under the slope degree of almost $2^{\circ}(50 \%)$} & \\
\hline & E, NE, SW & $\mathrm{N}, \mathrm{NE}, \mathrm{W}$ & S, SW & \\
\hline \multicolumn{5}{|c|}{ Sand, sand clay, turf } \\
\hline Coniferous forest & 900 & 1200 & 1400 & 300 \\
\hline Mixed forest & 1100 & 1300 & 1600 & 425 \\
\hline Deciduous forest & 1100 & 1400 & 1700 & 450 \\
\hline $\begin{array}{l}\text { Arable land along the slope, multi-year } \\
\text { fallows such as pastures, virgin land }\end{array}$ & 2800 & 3500 & 4200 & 1100 \\
\hline \multicolumn{5}{|c|}{ Light and medium loam } \\
\hline Coniferous forest & 1350 & 1800 & 2100 & 580 \\
\hline Mixed forest & 1500 & 1950 & 2400 & 640 \\
\hline Deciduous forest & 1650 & 2100 & 2500 & 670 \\
\hline $\begin{array}{l}\text { Arable land along the slope, multi-year } \\
\text { fallows such as pastures, virgin land }\end{array}$ & 2200 & 5250 & 6300 & 5150 \\
\hline \multicolumn{5}{|c|}{ Heavy loam, clay } \\
\hline Coniferous forest & 1800 & 2400 & 2800 & 780 \\
\hline Mixed forest & 2000 & 2600 & 3200 & 850 \\
\hline Deciduous forest & 2200 & 2800 & 3400 & 900 \\
\hline $\begin{array}{l}\text { Arable land along the slope, multi-year } \\
\text { fallows such as pastures, virgin land }\end{array}$ & 5600 & 7000 & 8400 & 2200 \\
\hline
\end{tabular}

getting quickly dry, it does not expand, and it is not sticky. That kind of soil is stable in dry and moist conditions, because it combines positive features of sandy (high internal friction and sufficient permeability) and clay (adhesion in dry conditions) particles. Light loam is characterized by poor plasticity. Light loamy soil is viscous and has insignificant water permeability. Plasticity, stickability, expansion, and capillary properties are mainly manifested along with the increased number of clay particles. Medium loam is medium plastic and has properties similar to heavy loamy soils. It is characterized by a greater height of the capillary rising of water, and the ability to transition into a floating state under humidifying conditions. Heavy loamy soil is very plastic, and in dry conditions, it has considerable viscosity and density. The soil is hardly treated. After humidifying, the soil stays wet for a long time and is characterized by low water permeability. Plasticity, stickability, expansion, water capacity, and capillary properties are much expressed. Clay is highly elastic, and is often characterized by a high density and cohesion. It is almost completely water resistant and is hardly treated. It is very sticky and expands quickly. The capillary properties are less expressed than in the loam and dust soils.

Considering the fact that forests serve a significant water-protection function, the borders of the water protection zones within forests are not determined.

\section{CASE STUDY: THE SERET RIVER}

The presented algorithm for the development of a land management project, including the establishment of water protection zones and near-shore protective belts, is here confirmed by investigation and analysis of the case of the river Seret in the Zalishchyky district of the Ternopil region (see: Fig. 1).

The preparatory work included the study and analysis of the local topography, flooding, intensity of bank erosion, constructions of engineering protection 
Table 2. Characteristics and values of the coefficients of transition from the reference width of the water protection zone to the actual width, with the consideration of the existing slope conditions

\begin{tabular}{|c|c|c|}
\hline Coefficient & Explanation & Values of the coefficients \\
\hline $\mathrm{K}_{1}$ & The coefficient of transition for various landforms & $\begin{array}{l}\text { Carpathians }-0.4-0.3 \\
\text { Polissia }-0.7-0.3 \\
\text { Forest-Steppe }-0.6-0.4 \\
\text { Steppe }-0.8-1.15 \\
\text { Crimea }-0.7-0.4\end{array}$ \\
\hline $\mathrm{K}_{2}$ & $\begin{array}{l}\text { The coefficient of transition for various landforms and land } \\
\text { covers for watercourses of the } 1 \text { st order }(50 \mathrm{~km}<\mathrm{L}<20 \mathrm{~km} \text {, } \\
\text { where } \mathrm{L} \text { - stands for the length of the river, } \mathrm{km}) \text {. For streams up } \\
\text { to } 50 \mathrm{~km} \text { long, it is equal to } 0.5 \text {. }\end{array}$ & $\begin{array}{l}\text { Forest zone (conifer) }-0.56 \\
\text { Forest zone (mixed, deciduous) }-0.35 \\
\text { Forest-Steppe }-0.30 \\
\text { Steppe }-0.25\end{array}$ \\
\hline $\mathrm{K}_{3}$ & $\begin{array}{l}\text { The coefficient of transition from deciduous forest to other forest } \\
\text { types }\end{array}$ & $\begin{array}{l}\text { Deciduous }-1.0 \\
\text { Mixed }-0.92 \\
\text { Coniferous }-0.85 \\
\text { Bare slope }-2.5\end{array}$ \\
\hline $\mathrm{K}_{4}$ & $\begin{array}{l}\text { The coefficient of transition from sandy loam to soils of another } \\
\text { texture }\end{array}$ & $\begin{array}{l}\text { Light (sand, sandy loam, turf) }-1.0 \\
\text { Medium (light and medium loam) }-1.5 \\
\text { Heavy (viscous loam, clay, rocky soils) }-2.0\end{array}$ \\
\hline $\mathrm{K}_{5}$ & $\begin{array}{l}\text { The coefficient of transition from northern exposure to other } \\
\text { exposures }\end{array}$ & $\begin{array}{l}\text { Slope exposure: } \\
\mathrm{NE} \text { and } \mathrm{W}-1.0 \\
\mathrm{E}, \mathrm{SE}, \mathrm{NW}-0.8 \\
\mathrm{~S} \text { and } \mathrm{SW}-1.2\end{array}$ \\
\hline $\mathrm{K}_{6}$ & $\begin{array}{l}\text { The coefficient of transition from a forest-covered slope to a bare } \\
\text { slope }\end{array}$ & $\begin{array}{l}\text { Plowing across the slope }-1.6 \\
\text { Plowing along the slope and perennial } \\
\text { fallows }-2.4 \\
\text { Fallows under pastures and virgin land }-2.6\end{array}$ \\
\hline
\end{tabular}

of banks, as well as target use of the land plots, which were expected to belong to the territory of the water protection zone. The preparatory work has determined that the length of the river Seret equals $250 \mathrm{~km}$, and the area of the river basin is $3900 \mathrm{~km}^{3}$. The upper channel is moderately winding. The width of the channel in the upper stream equals $4-10 \mathrm{~m}$, whereas in the lower part it is from 10-20 to $35-50 \mathrm{~m}$ and more. The valley of the upper stream is wide, symmetrical, and in some places it is canyon-like (on some plots it is $0.5-0.8 \mathrm{~km}$ wide). In the upper section, the flood plain is two-sided, waterlogged, whereas in the middle and lower streams, it is jumping, mostly $0.1-0.2 \mathrm{~km}$ wide. The river inclination makes $0.93 \mathrm{~m} \cdot \mathrm{km}^{-1}$. The supply of the river Seret is of mixed type, mainly due to snow and rain. The freezing over of the river Seret lasts from late December to March.

\section{Discussion of water protection zones in Ukraine and results of the Seret river case study}

In Ukraine, land relevant to the water fund occupies 2422.5 thousands ha or $4.01 \%$ of the country's territory, including natural stream flows (rivers and streams) -241.2 thousands ha (10.0\%); man-made stream flows (channels, collectors, ditches) -179.8 thousands ha (7.4\%); lakes, near-shore closed water bodies, estuaries -873.6 thousands ha $(36.1 \%)$; ponds - 336.5 thousands ha (13.9\%); man-made water-storage reservoirs -791.4 thousands ha (32.7\%) (Official website of the State... 2020).

During the last decades, almost all surface sources of water supply have become or continue to be intensively polluted. Natural sources of river pollution include soil erosion, dead flora and fauna, whereas anthropogenic sources include pesticides and fertilizers, 


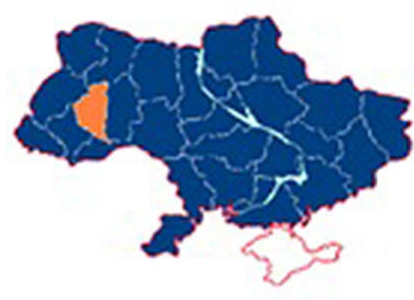

Y
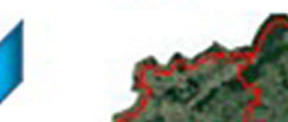
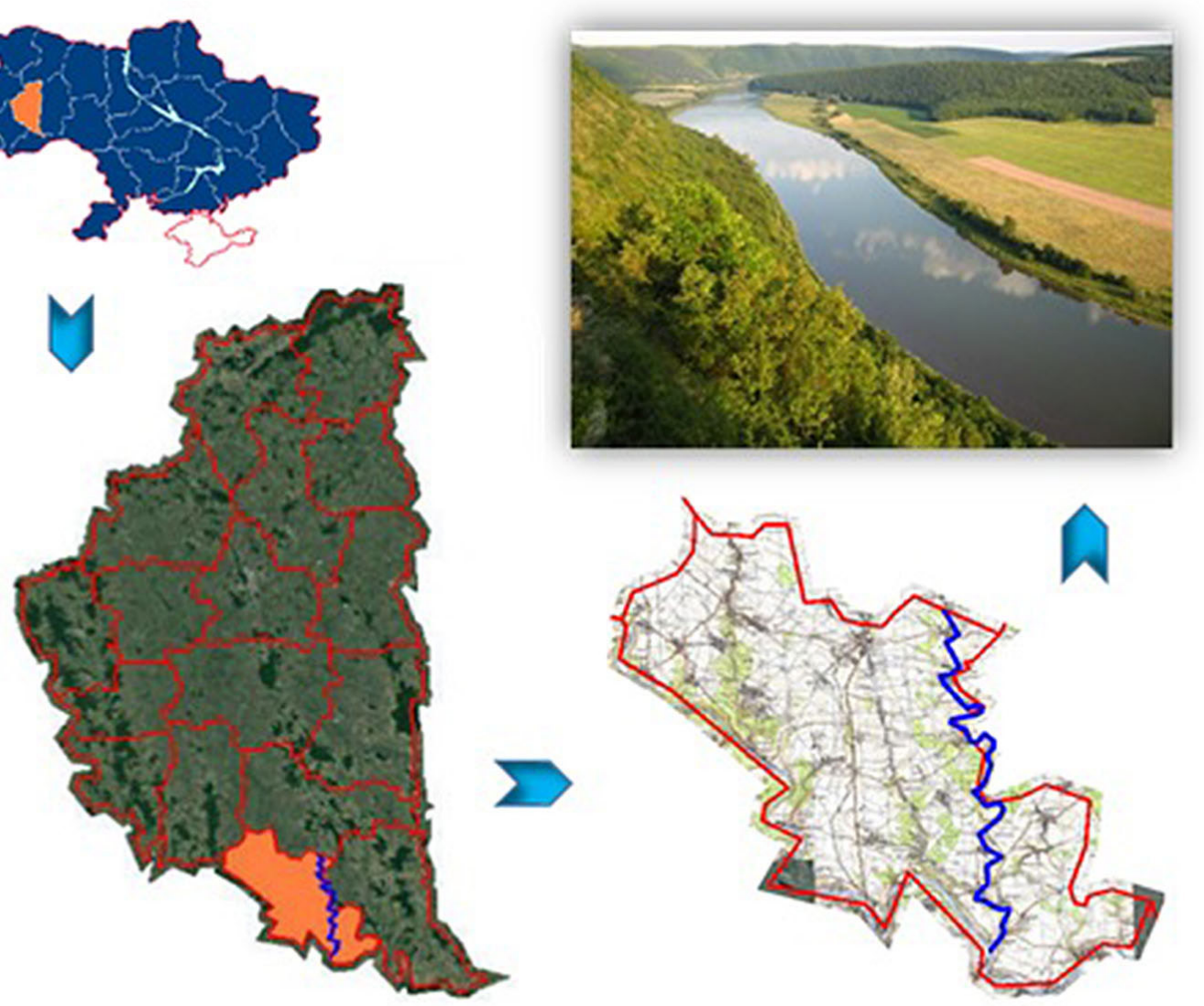

Fig. 1. The river Seret in Zalishchyky olistrict of Ternopil region (Source: Completed by the authors according to the data (Official website of the state... 2020)

penetrating into water bodies in the process of economic activities of people, particularly while growing agricultural crops.

The regulatory and methodical basis for imposing water-protection restrictions in land use is currently supplied by the Water Code of Ukraine of June 6, 1995 № 213/95-BP (Water Code of Ukraine, 1995); Land Code of Ukraine of October 25, 2001 № 2768-III (Land Code of Ukraine, 2001); Resolution of the Cabinet of Ministers of Ukraine of May 8, 1996 № 486 “On approval of the Order of determination of sizes and borders of water protection zones and regime of economic activities within their territory" (About the statement of the Order... 1996); SBS 360-92 "City planning. Planning and building up urban and rural settled areas" (DBN $360-92 \ldots$ 1992).

Special regulations concerning land use limit different kinds of economically significant or other legal activity on the territory of the zones of land use in order both to secure rights of landowners and to protect the general population from harmful impacts of human activity, including production of various sorts. Specific regulations of land use are determined by the system of land use restrictions (Kuryltsiv and Hernik, 2014).

Water protection zones are established in order to develop a favorable regime of water bodies and processes, to prevent their pollution, exhaustion, destruction of near-water plants and animals, as well as to reduce flow fluctuations along the rivers, seas, and around lakes, water-storage reservoirs, and other water bodies. The obligations for creating water protection zones include flood plains, terraces above the flood plains, edges and steep slopes of banks, as well as near-water gills and ravines.

In a water protection zone, it is necessary to maintain the regime of regulated economic activity; partic- 
ularly on the territory of the water protection zone it should be forbidden to:

- use long-lived and intensive pesticides;

- locate for cemeteries, animal burial sites, waste deposits, fields of filtration;

- dispose of production, e.g., dirty waste waters with the use of gills, pits, streams, etc.

Within the water protection zones, there are specified areas of near-shore protective belts, which create a protected territory through a regime of restricted economic activities. Thus, the near-shore protective belts can be used for the introduction of economic activities under conditions that mandate respect for specific requirements, as approved by article 89 of the Water Code of Ukraine (Water Code of Ukraine, 1995).

Thus, in the near-shore protective belts along the rivers, around water bodies and on islands, it is forbidden to (Water Code of Ukraine, 1995):

1) plow lands (with an exception of soil for grassing and foresting), as well as pursue goals involving horticulture and vegetable-growing;

2) store and apply pesticides and fertilizers;

3) arrange summer camps for cattle;

4) conduct construction activities (except for building hydro-technical, navigation, hydro-metrical and linear, as well as engineering-technical and fortification structures, fences, border posts, border lanes, communication devices), e.g., thus excluding recreation-related areas, dachas, garages, and parking areas for cars;

5) wash and maintain vehicles;

6) arrange waste disposals, dung pits, collectors of liquid and solid wastes from production, cemeteries, animal burial sites, filtration fields, etc.

Objects, which are located within the area of a near-shore protective belt, may be allowed to remain if the regime is not violated. Structures that cannot be used, as well as those, which do not conform to the required regime of economic activities, should be removed from the near-shore protective belt.

Considering the above-mentioned fact, the most important water protection restrictions concerning land use should include water protection zones and near-shore protective belts, which are to perform the function of a "natural barrier" between a water object and man-made results of economically driven produc- tion including built structures, which may negatively influence the conditions and quality of water.

It is worth noting that at present, water protection zones and near-shore protective belts are not established. The situation complicates the process of introducing those restrictions into the State land cadaster and enforcing the compliance on the part of landowners and land-users of land plots in areas subjected to those restrictions.

Thus, while developing measures on water protection from pollution, the urgent task is to set restrictions on the use of land plots of relevant sizes, determined by the projects of land management. In a consolidated form, differentiation of the normative requirements for the determination of borders of water protection zones and near-shore protective belts are presented within and outside the borders of settlements in Table 3.

However, the normative requirements, mentioned in the table, concerning the determination of borders of water protection zones and near-shore protective belts around rivers and water bodies are still not implemented in Ukraine. Such measures must be established, according to relevant societal norms of Ukraine, for the sake of environmental protection and improvement. Currently, in the State land cadaster, there is almost no information on water-protection restrictions in the use of land. This creates ample opportunities for misunderstandings and abuses while using near-water land, and contributes to its intensive degradation.

Such conditions in the field of use and protection of land are linked first and foremost with imperfect land reform. A legitimate aim of land reform is to continue transformation of the system of land relations in the direction of establishing different forms of allowable land ownership and performance of different types of allowable economic activities. The imperfect state regulation of the transformation process has contributed to the intensification of problems of a legal and environmental character. Changes in the forms of land ownership have perversely generated violation of the optimal organization of land use and negatively influenced the fulfillment of measures for sustainable management of land use (Kuryltsiv et al., 2018).

The situation of unregistered water-protection restrictions on land use has led to uncontrolled privatization and building up in the shoreline zones, placing the sources of water pollution and other negative phenom- 
Table 3. Specification of normative requirements for borders of water protection zones and near-shore protective belts around rivers and water bodies

\begin{tabular}{|c|c|}
\hline OUTSIDE SETTLEMENTS & WITHIN SETTLEMENTS \\
\hline \multicolumn{2}{|l|}{ Water protection zone } \\
\hline $\begin{array}{l}\text { This normally refers to the available contours of agricultural lands, communication } \\
\text { routes, forest belts, borders of flood plains, terraces above flood plains, edges of } \\
\text { slopes, gills, and ravines, and is determined by a line, which is the most remote } \\
\text { from the water object, i.e. flooding under a maximal surface (flooding) level } \\
\text { of water, which is repeated once in a ten-year period; wearing away of banks, } \\
\text { meandering; temporary and permanent flooding of land; erosion activity; bank } \\
\text { slopes and much-eroded lands. The external border of a water protection zone } \\
\text { on the lands of rural settlements, lands of agricultural intended use, forest fund, } \\
\text { on the territories of water, forest, fishing enterprises, as well as on the lands of } \\
\text { other owners and users is determined with consideration of the zone of sanitary } \\
\text { protection of the sources of fresh water supply, expected shoreline erosion; forest } \\
\text { plants, which greatly contribute to the protection of water with an external border } \\
\text { not less than } 1000 \text { meters from the water level in a rainless period; all lands of } \\
\text { derivation on the existing reclamation systems, but not less than } 200 \text { meters from } \\
\text { the edge of channels or seawalls. }\end{array}$ & $\begin{array}{l}\text { The sizes of water protection zones } \\
\text { are determined with consideration of } \\
\text { the topography, vegetation cover, and } \\
\text { character of the zone use, and are agreed } \\
\text { to by the authorities responsible for the } \\
\text { regulation of use and protection of water } \\
\text { and land, including local bodies of state } \\
\text { executive power. When planning new } \\
\text { settlements, sizes of water protection } \\
\text { zones should be not less than } 500 \mathrm{~m} \text { in } \\
\text { case of water protection zones; } 100 \mathrm{~m}- \\
\text { for small rivers up to } 50 \mathrm{~km} \text { long; } 200 \mathrm{~m} \\
\text { - for small rivers } 50-100 \mathrm{~km} \text { long; } 300 \mathrm{~m} \\
\text { - for small rivers above } 100-200 \mathrm{~km} \mathrm{long} \text {. }\end{array}$ \\
\hline \multicolumn{2}{|l|}{ Near-shore protective belt } \\
\hline $\begin{array}{l}\text { Near-shore protective belts are established on the river banks and around water } \\
\text { bodies along the waterline (in the rainless period), specifically of the following } \\
\text { width: } 25 \mathrm{~m} \text { - for small rivers, streams, as well as ponds of an area less than } 3 \\
\text { hectares; } 50 \mathrm{~m} \text { - for medium rivers, water-storage reservoirs, placed on such areas, } \\
\text { and ponds with an area above } 3 \text { hectares; } 100 \mathrm{~m} \text { - for large rivers, with water- } \\
\text { storage reservoirs placed on them, and lakes. If the degree of slope exceeds three, } \\
\text { the minimal width of the near-shore protective belt should be doubled. Near-shore } \\
\text { protective belts are established on land plots of all categories of land. }\end{array}$ & $\begin{array}{l}\text { Shoreline belts of rivers are established } \\
\text { on both banks along the waterline (in } \\
\text { the rainless period) with a width of up to } \\
100 \mathrm{~m} \text { - for rivers of above } 100 \mathrm{~km} \text { long; } \\
\text { up to } 50 \mathrm{~m} \text { - for the rivers } 50-100 \mathrm{~km} \\
\text { long; not less than } 20 \mathrm{~m} \text { - for rivers up to } \\
50 \mathrm{~km} \text { long. Along the banks of a water } \\
\text { body, the shoreline belts are established } \\
\text { with a width of no less than } 20 \mathrm{~m} \text { from } \\
\text { the waterline, which corresponds to the } \\
\text { normal banked up water level. }\end{array}$ \\
\hline
\end{tabular}

ena within those areas. Inconsistency of land reform implementation has resulted in a considerable number of land plots, intended for private peasant farming, being delivered to ownership and private use without consideration of the standards for establishment of water-protection restrictions. This contradicts current laws and approved norms. Such contradictions have been necessitated by issue of state acts certifying the right of land ownership in the late 1990s. According to these mechanisms, land plots were established only in local systems of coordinates without reference to the national Ukrainian geodesic network.

Another problem, which is typical for Ukraine because of no national control of the bodies of state power and local government for compliance with the requirements of land laws, is the unauthorized occupation and use of lands for agricultural activity within the water protection zones, with no legal approval.

Thus, nowadays, the development of a land management project on the determination of water protection zones and near-shore protective belts, with a specific regime of farming on the relevant territory, should become one of the most important mechanisms to improve the water-ecological situation, hydrological regime, and sanitary-hygienic conditions of water bodies and processes. The projects should be developed at the request of the authorities responsible for water economy and other specifically authorized bodies. The project goal is to create administrative-territorial formations, where the water body is located, that 
would be subjected to the regime of the water protection zone. The algorithms of such project development should be coordinated with detailing preparatory, project, economic-legal, and coordinating measures (see: Fig. 2).

The presented algorithm for developing a land management project pertaining to the establishment of water protection zones and near-shore protective belts is illustrated with the example of the river Seret in Zalishchyky district of Ternopil region (see: Fig. 3).

The next stage of project development involves projecting of a water protection zone, which includes the specification of its internal and external borders. The internal border of a water protection zone coincides with a minimal water level in the water object. The external border of a water protection zone normal-

Stages of development of a land management project concerning establishment of water protection zones and near-shore protective belts

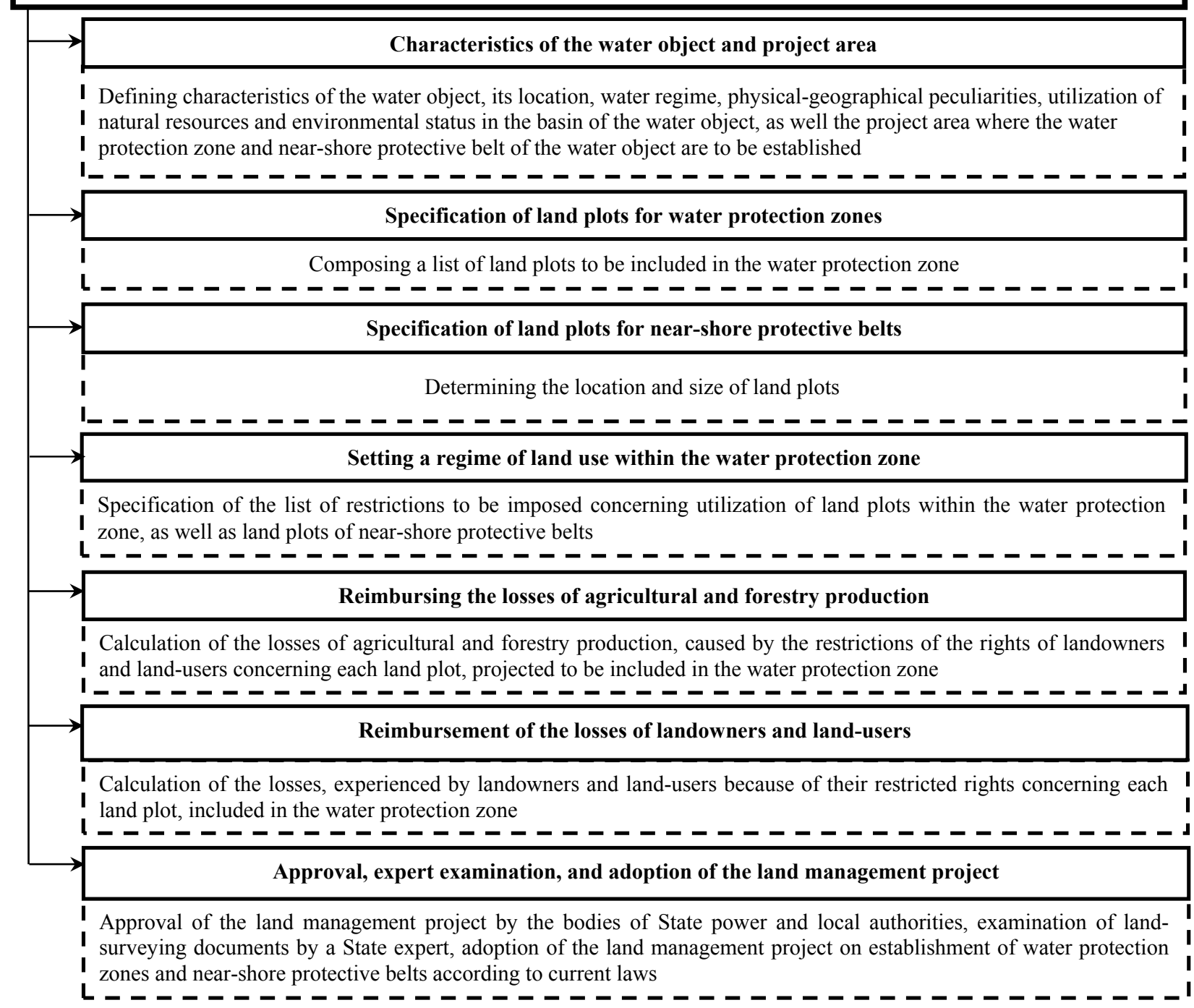

Fig. 2. Elements of development of a land management project on the establishment of water protection zones and nearshore protective belts 

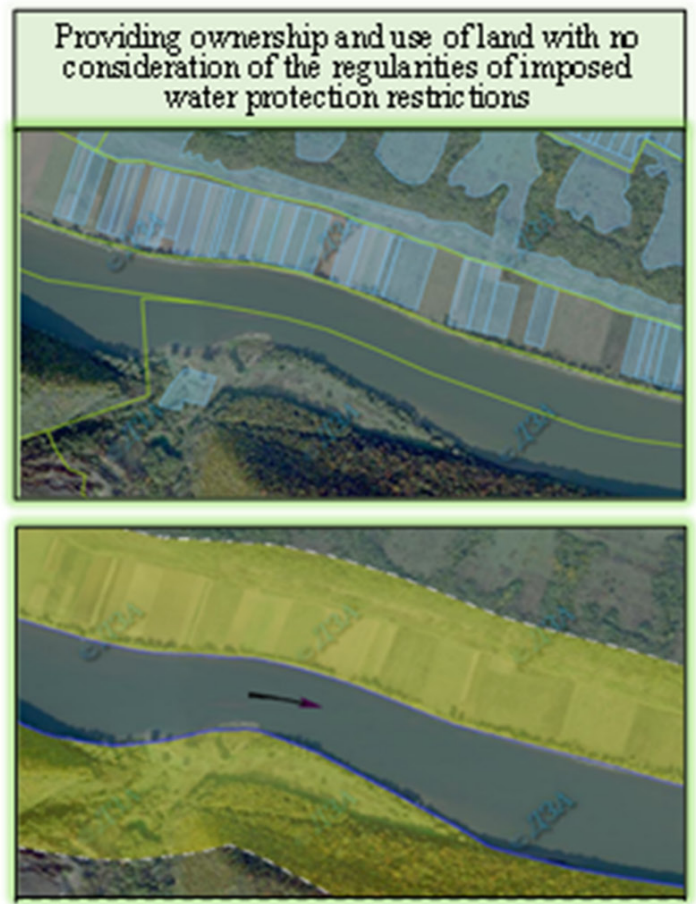

Establishing a water protection zone at the distance of $250 \mathrm{~m}$ from the waterline

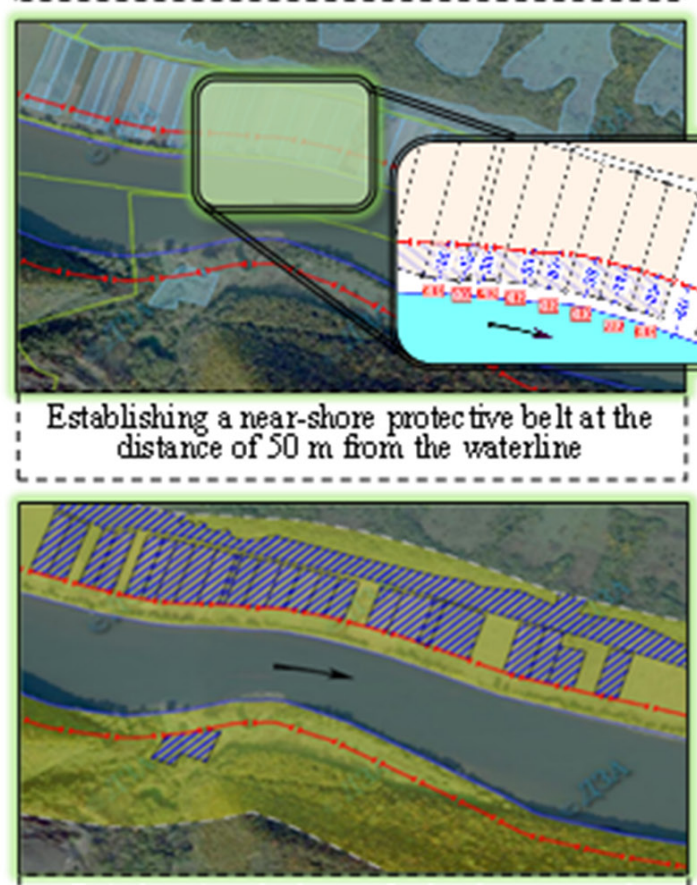

Reimbursing the losses for landowne rs and land-users

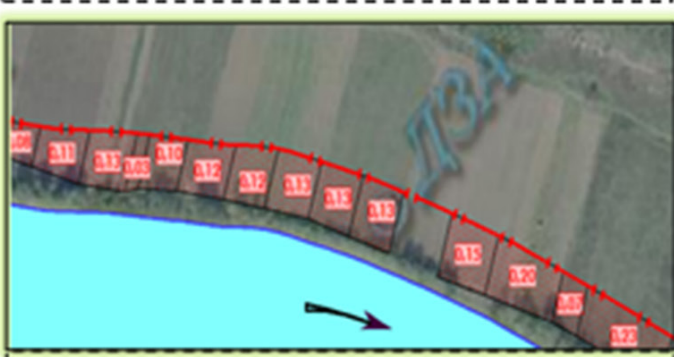

Re imbursing the losses of agricultural production

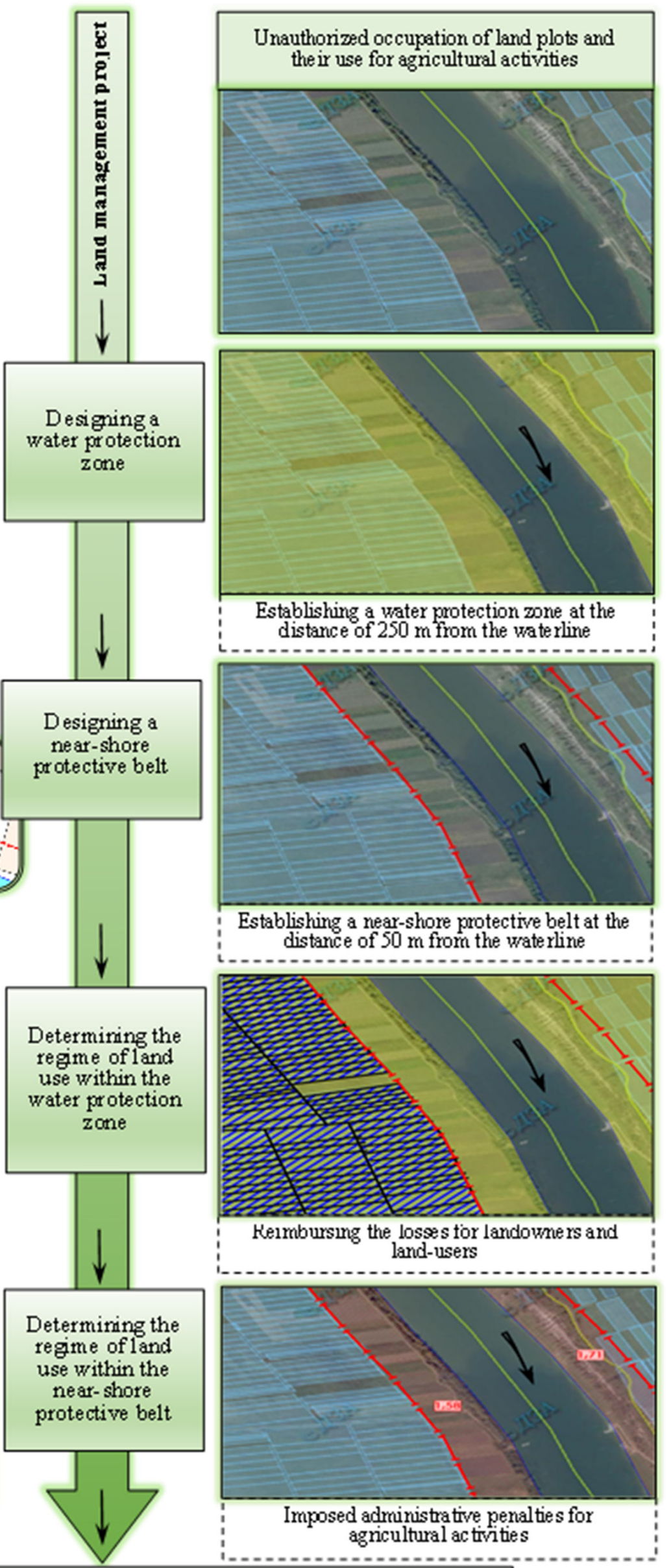

Submitted to the State Geocadaster for State expert examination

Fig. 3. The scheme for the development of land management project incorporating the establishment of water protection zones and near-shore protective belts on the river Seret in Zalishchyky district of Ternopil region 
ly refers to the available contours of agricultural lands, roads, forest belts, borders of flood plains, terraces above flood plains, edges of slopes, gills and ravines, and is determined by the line of the 10 -year flood.

While projecting the external border of the water protection zone of the river Seret, the researchers used data, provided by the affiliate of the State Agency of Water Resources of Ukraine in the Ternopil region, Department of Ecology and Natural Resources, and the Ternopil regional state administration to define the line, which is the most remote from the water object.

Moreover, they considered zones of sanitary protection of the sources of fresh water, as well as the expected zone of shoreline erosion (determined by referring to the data from specialized hydrological observations); geomorphological and hydrological conditions, as well as expected mudflow and landslide phenomena. In the design process, it had been determined that for the conditions of the Seret river, there is no significant bank destruction or erosion activity, the line of flooding is narrow, and thus, the width of the water protection zone equals $250 \mathrm{~m}$. There is a set regime of land use within the water protection zone. The regime imposes some restrictions.

A near-shore protective belt for the Seret river is established on the riverbank along the waterline (in the rainless period) that is $50 \mathrm{~m}$ wide. In the designing process, the scientists detected overlapping of the borders of the water protection zone and near-shore protective belt over land plots, which fall within private ownership or use.

A discussion should be undertaken between landowners and local or other-level state institutions responsible for water protection policy about the problem of the water protection zone overlapping farming areas, and specific recommendations should become part of management practice.

To solve the aforementioned problem, the project proposes to withdraw the portions of the land plots, which overlap with the near-shore protective belt of the river, supplemented by subsequent reimbursement of the losses of agricultural production for landowners. In turn, the land plots, which appear within the water protection zone are also subjected to restrictions, and their owners get loss reimbursement.

Development of the land management project, along with the imposition of restrictions on the use of agricultural land, also requires devising measures for water protection from pollution that is caused by the penetration of nitrates from agricultural sources. Implementation of those regulations will enable restrictions on the regime of farming of corresponding territory.

The developed project of land management should be submitted to state expert examination, which is conducted through the consideration of documents and materials, and if necessary - by observation in physical terms (field research). During state expert examination, the experts study, check, analyze and assess the following aspects: first and foremost, the conformity with the requirements of laws and approved standards, norms, and rules in project decisions; also, the conformity of measures, required by the documents and materials, with the tasks of rational use and protection of land, as well as noting the legal rights and interests of owners and users of land plots, and the rights and interests of state and society; environmental-economic efficiency of project decisions with respect to preventing their negative impact on land resources' condition; taking into account the neighboring land plots and topography.

\section{Discussion of water protection zones in other countries}

Surface water protection zones have been established in various countries. Examples are: Uganda, where clear guidelines for the delineation of a protection zones of thirty to one hundred meters from the highest watermark in a river were adopted (Uganda, 2000) and Cyprus (Cyprus, Ministry of Agriculture, Natural Resources and Environment 2010) where Close Protection Zones were established to keep reservoirs and rivers away from pollution, which can be transported by direct surface or subsurface runoff. In Cyprus, the perimeter depends on catchment slope; for slopes lower than $3 \%$, from $3 \%$ to $10 \%$, and from $10 \%$ to $20 \%$ the width of the zones are 100,200 , and 300 meters, respectively. The width is measured independently on both sides of the river, from the riverbanks, and perpendicularly to the stream centerline. For narrow rivers, the above distances are measured from the stream centerline and are set at 105, 205, and 305 meters, respectively. Thus, the methodologies used in Uganda and Cyprus demonstrably differ from the methodolo- 
gy used in Ukraine, and the regulations differ from one country to another.

Planning regulations that protect drinking water zones also exist in many countries. Not only rivers, but also any other drinking water sources, such as wells and springs are usually considered in legal (state-wide or local) regulations in these countries. Examples are: Canada/Ontario where natural water sources that supply municipal drinking water systems are protected by law (Ontario: Ministry of the Environment, Conservation and Parks, 2017), UK where raw surface waters abstracted from rivers and reservoirs within Drinking Water Protected Areas are protected by water companies and Environment Agency so as not to be polluted (UK, Environment Agency), (EPA Abstractt) and Jordan where several groundwater and surface water protection zones were delineated and monitored by state institutions (Subah and Borgstedt 2008). In Turkey, protection zones for a freshwater reservoir are divided into four categories: (1) absolute protection zone (maximum water level-300 m), (2) short-range protection zone (300-1000 m), (3) medium-range protection zone (1000-2000 m) and (4) long-range protection zone (2000 m-watershed) (Özdemir, 2020).

In the US, the federal Environmental Protection Agency (EPA) has funded many research studies of water resources, including rivers, in relation to land use (EPA website, accessed August 2, 2020). The EPA has sometimes funded such research in conjunction with the National Science Foundation (NSF) and/or the US Department of Agriculture (USDA) (See Abstracts from conference in Virginia, Bosch, 2001). Nevertheless, the actual effective real-world implementation of such studies is, irregular, and deserves ongoing evaluative research in itself.

In China, as in some research projects in the US, there are cases of research aimed at an "integrated" study of environmental decision-making about water resources, including rivers and river basins, namely research that includes extensive analysis of the attitudes of persons and organizations interested in water resource environmental decision-making, beyond an emphasis on the physical and biological science aspects of the relevant water resource environments. Both types of research projects (and there is perhaps no sharp distinction between the two types of research projects) have their merits and limitations. For examples of self-avowedly "integrated" approaches, see discussions identified here (Sankowski, 2001; Meo et al. 2002; Meo, 2007; Kumar, et al., 2019), (EPA published Abstract of funded project, Ecological Risks, Stakeholder Values and River Basins: Testing Management Alternatives for the Illinois River EPA Grant Number: R825791).

\section{CONCLUSIONS}

The integration of the proposed approaches to imposing water protection restrictions of land use should be considered as an important step along the way of Ukraine's reforming the current organizational-legal system of regulation of near-shore land use, because its ineffectiveness has been vividly manifest in recent decades of land reform implementation.

We take the view in this article that the rivers of Ukraine are natural resources that belong to the people of Ukraine. Thus we object to forms of privatization of land resources near rivers (or rivers themselves) that clash with well-formulated national law about the care for river waters as a public good (including, but not limited to the case of the Seret river,). Presumably, the rightful sovereign authority of the nation-state of Ukraine (at the present time) rests on its struggle for nation-state democracy, and a state with significant real-world (and not solely normatively affirmed) sovereignty. For a discussion of comparable normative issues in the US context, see Sankowski, 2001. However, the pragmatics of language that implies affirmation of democratic nation-state legitimacy can be very different in different political situations, as in the US and in contemporary Ukraine. This raises complex normative issues about language and its relation to the actual world of environmental decision-making. The "pragmatics" of spoken and written language is an important area of contemporary research, which has relevance to environmental sciences research and expression of its claims. For a handbook about contemporary pragmatics, see Yan Huang, 2017.

We do not of course reject privatization as such, but we maintain that excessive privatization (or some types of privatization of river-related land and water) threatens the environment in Ukraine. Our respect for some private-property norms is obvious, for example, in our inclusion of considerations about respect for land ownership and in some cases, compensation for 
government restrictions on private use of property that might pollute.

Water protection restrictions, defined according to fundamentals of land (and water) management, will contribute to establishing a favorable regime of water objects, preventing pollution, exhaustion, and extinction of near-water plants and animals, as well as reducing flow fluctuation along the rivers.

The establishment of water protection zones around rivers, which include zones of enforced restrictions of economic activity, e.g., by establishing near-shore protective belts, is one of the means to prevent penetration of nitrogen compounds into the water runoff and internal water bodies, which are located near places of agricultural production.

The establishment of water protection zones and near-shore protective belts for water objects, along with setting up a regime of specific land use and economic activities on the relevant territory, will contribute to addressing the problem of topological disagreement of land plots, which are located within the area of restricted land use.

\section{REFERENCES}

Bosch, D., (ed.) (2001). Abstracts, Integrated Decision-Making for Watershed Management Symposium: Processes and Tools, VWRRC (Virginia Water Resources Research Center) Special Report SP7-2001 https://vtechworks.lib. vt.edu/bitstream/handle/10919/55235/sp072001.pdf

Council Directive 98/83/EC of 3 November 1998 on the quality of water intended for human consumption (1998). http://data.europa.eu/eli/dir/1998/83/oj

Council Directive 91/676/EEC of 12 December 1991 concerning the protection of waters against pollution caused by nitrates from agricultural sources (1991). http://data. europa.eu/eli/dir/1991/676/oj

Council Directive 91/271/EEC of 21 May 1991 concerning urban waste-water treatment (1991). http://data.europa. eu/eli/dir/1991/271/oj

Cyprus, Ministry of Agriculture, Natural resources and Environment, Water Development Department, Nicosia (2010). Reservoir Protection Zones, Method for determining the zones.

Directive 2000/60/EC of the European Parliament and of the Council of 23 October 2000 establishing a framework for Community action in the field of water policy (2000). http://data.europa.eu/eli/dir/2000/60/oj
Directive 2008/56/EC of the European Parliament and of the Council of 17 June 2008 establishing a framework for community action in the field of marine environmental policy (Marine Strategy Framework Directive) (2008). http://data.europa.eu/eli/dir/2008/56/2017-06-07

Kumar, P., Liu, W., Chu, X., Zhang, Y., Li, Z. (2019). Integrated water resources management for an inland river basin in China

Watershed Ecology and the Environment, 1, 33-38. https:// doi.org/10.1016/j.wsee.2019.10.002

Kuryltsiv, R., Hernik, J. (2014). Land use administration in Ukraine: restrictions and zoning regulations, Acta Scientiarum Polonorum, Formatio Circumiectus, Olsztyn. 13, 2, 51-58.

Kuryltsiv, R., Hernik, J., Kryshenyk, N., Zhydovska, N. (2018). Land inventory as the instrument for development of amalgamated territorial communities in Ukraine. Acta Scientiarum Polonorum, Formatio Circumiectus, 17(4), 97-108

Meo, M., Focht, W., Caneday, L., Lynch, R., Moreda, F., Pettus, B.,Sankowski, E., Trachtenberg, Z., Vieux, B., Willett, K. (2002). Negotiating Science and Values with Stakeholders in the Illinois River Basin. Journal of the American Water Resources Association, 38 (2), April 2002, 541-554.

Meo, M., (2007). The Illinois River Project and Oklahoma's Quest for Environmental Quality, Universities Council on Water Resources Journal of Contemporary Water Research \& Education, issue 136, 56-67.

New Brunswick, https://www2.gnb.ca/content/gnb/en/ departments/elg/environment/content/land_waste/ content/reference_manual/watershed_protection.html, accessed 24 July 2020

Ontario, Ministry of the Environment, Conservation and Parks, Municipal drinking water systems: licencing, registration and permits, published March 2017, updated February 2020

Özdemir, A. (2020). Determination of protection zones in drinking water basins: a case study from Turkey, Sapanca Lake Basin. Environ Earth Sci 79, 178; https:// doi.org/10.1007/s12665-020-08916-5

Sankowski, E. (2001). Environmental Management and Democratic Legitimacy, Special Issue: Environmental Policy in Oklahoma, Oklahoma Politics, 21-31.

Sankowski, E., Harris, B.J., Hernik, J. (2016). Some Problems and Possibilities for Sustainable Development. Krakow: Publishing House of the University of Agriculture in Krakow.

Subah, A., Borgstedt, A. (2008). Groundwater protection and sanitation - Practical experiences in Jordan, Coupling Sustainable Sanitation and Groundwater Protec- 
tion, Symposium to the International Year of Sanitation (IYS), October 14-17, 2008, Hannover, Germany.

Water Code of Ukraine (1995). https://zakon.rada.gov.ua/ laws/show/213/95-\%D0\%B2\%D1\%80

Holian, V., Sakal, O., Tretiak, N. (2015). Regulation of water protection zones as an important prerequisite for protection of waters from nitrate pollution from agricultural sources: institutional support and identification. Agrosvit, $23,3-12$.

DBN 360-92 Urban planning. Planning and construction of urban and rural settlements (1992). https://dbn.co.ua/ load/normativy/dbn/dbn 36092 ua/1-1-0-116

Land Code of Ukraine (2001). https://zakon.rada.gov.ua/ laws/show/2768-14

Land management. Land management projects for the creation of water protection zones. Development rules: standard of the State Committee of Ukraine for Land Resources: SOU SCLR 00032632-005:2009 (2009). sou dkzr_00032632_005_2009_zemleustriy_proekti_zemleustroyu (1)

Official website of the State Service of Ukraine for Geodesy, Cartography and Cadastre. http://land.gov.ua/

Pokydko, I., Martyn, A. (2012). A new concept of forming water protection restrictions in land use. Land Management Bulletin, 7, 34-40.
About the statement of the Order of definition of the sizes and borders of water protection zones and their regime of conducting economic activity : Resolution of the Cabinet of Ministers of Ukraine of May 8, 1996, No 486. https://zakon.rada.gov.ua/laws/show/48696- $\% \mathrm{D} 0 \% \mathrm{BF}$

Uganda, 2000. The National Environment (Wetlands, River Banks And Lake Shores Management) Regulations, 3, STATUTORY INSTRUMENTS 2000

UK, Environment Agency, https:/data.gov.uk/dataset/ 3d136e9a-78cf-4452-824d-39d715ba5b69/drinkingwater-protected-areas-surface-water, accessed 24 July 2020

ADD REFERENCE: USEPA, US Environmental Protection Agency, https://www.epa.gov/environmental-topics/water-topics

USEPA, Abstract describing EPA/NSF/USDA funded project, Ecological Risks, Stakeholder Values and River Basins: Testing Management Alternatives for the Illinois River EPA Grant Number: R825791; https://cfpub.epa. gov/ncer_abstracts/index.cfm/fuseaction/display.abstractDetail/abstract/843

Yan Huang, (ed.) (2017). The Oxford Handbook of Pragmatics. Oxford: Oxford University Press.

\section{INTEGRACJA OCHRONY WÓD POWIERZCHNIOWYCH W GOSPODAROWANIU GRUNTAMI NA UKRAINIE: STUDIUM PRZYPADKU RZEKI SERET}

\section{ABSTRAKT}

\section{Cel pracy}

Celem artykułu jest analiza obecnie stosowanych, a także zbadanie potencjalnych nowych podejść do planowania i wdrażania ograniczeń związanych z ochroną wód, mających na celu regulację użytkowania gruntów.

\section{Materiały i metody}

Proponowane podejście do ochrony wód powierzchniowych sugeruje nałożenie prewencyjnych ograniczeń w użytkowaniu gruntów. To z kolei wymaga opracowania projektu zarządzania zagospodarowaniem terenu - czyli planu zagospodarowania, który uwzględniałby te kwestie. Projektowanie stref ochrony wód i przybrzeżnych pasów ochronnych opiera się na rozważeniu scenariuszy generowanych w drodze modelowania geoinformacji i na wykorzystaniu danych teledetekcyjnych. ArcGIS 10.7 wykorzystano jako podstawowe oprogramowanie do wykonywania analizy przestrzennej danych. Obszar badawczy, który posłużył do weryfikacji proponowanych metod projektowania stref ochronnych wód i przybrzeżnych pasów ochronnych, obejmował część rzeki Seret i jej dorzecza, znajdującą się w granicach administracyjnych powiatu zaliszczyńskiego, w obwodzie tarnopolskim, na Ukrainie.

\section{Wyniki i wnioski}

Wyniki badań pokazuja, że opracowanie projektu zagospodarowania terenu poprzez ustanowienie stref ochronnych wód i przybrzeżnych pasów ochronnych (z określonym reżimem gospodarowania w odpowied- 
nich granicach) powinno stać się jednym z najważniejszych mechanizmów zapobiegania skażeniom, zmniejszania ryzyka powodzi i poprawy warunków sanitarno-higienicznych jednostek wodnych oraz dotyczących och działań i procesów. Opracowując projekt zagospodarowania terenu, autorzy wykonali obliczenia szerokości strefy ochronnej wód zgodnie z zasadą wartości referencyjnej, określając optymalną szerokość pasa wychwytującego spływ powierzchniowy.

Słowa kluczowe: ochrona środowiska, zagospodarowanie terenu, strefa ochrony wód, ograniczanie ryzyka powodziowego, przybrzeżny pas ochronny 